\title{
Vətəndaş elmi layihələrində fərdi məlumatların təhlükəsizliyinin təmini məsələləri
}

\author{
Nərgiz Verdiyeva \\ AMEA İnformasiya Texnologiyaları İnstitutu, Bak1, Azərbaycan \\ depart3@iit.science.az
}

\begin{abstract}
Xülasə- Məqalə vətəndaş elmi layihələrində könüllü əsaslarla iştirak edən vətəndaşların fərdi məlumatlarının təhlükəsizliyinin təmin edilməsi məsələlərinə həsr olunmuşdur. Vətəndaşların fərdi məlumatları kateqoriyalara bölünərək təsnif edilmişdir. Fərdi məlumatların təhlükəsizliyinin mühafizəsini təmin edən normativ-hüquqi sənədlər nəzərdən keçirilmişdir. Mövcud vətəndaş elmi layihələrində vətəndaşların fordi məlumatlarının qorunması yolları təhlil edilmişdir. Aparılmış tədqiqatlar əsasında ölkəmizdə bu istiqamətdə görülmüş işlər təhlil edilmiş vo təkliflor verilmişdir.
\end{abstract}

Açar sözlor-e-elm; votəndaş elmi; təhlükosizlik; fordi molumatlar; sensitiv molumatlar.

\section{GİRIŞ}

E-elmin yeni istiqaməti kimi formalaşan vətəndaş elmi İKT sahəsində əldə olunan nailiyyətlərin təsiri ilə sürətlə inkişaf etməkdədir. Oşyaların interneti, şəbəkə və bulud texnologiyalarının tətbiqi ilə bu inkişaf getdikcə artmaqdadır. Vətəndaş alimlər şəbəkə mühitində elmi tədqiqatlara töhfə vermək məqsədilə öz resurslarını şəbəkəyə qoşur, "ağıllı" telefonlar, planşetlər və digər qurğular müvafiq layihələrin həyata keçirilməsinə şərait yaradır. Vətəndaş elmi layihələrində toplanılan və emal olunan verilənlər böyük verilənlər (Big Data) problemini yaratdığından burada bulud texnologiyalarının imkanlarından istifadə olunur. Açıq kodlu proqram təminatı və bulud hesablamaları (cloud computing) yüksək məhsuldarlıqlı hesablamaların təmin edilməsi xərclərini xeyli azaldır.

İctimaiyyətin rolunun artması nəticəsində vətəndas elmi ənənəvi elmdən daha çox müxtəliflik və çeviklik nümayiş etdirir. Vətəndaş elminin reallaşdırılması vasitəsi olan vətəndaş elmi layihələri elmdə mütəxəssislərlə yanaşı, adi vətəndaşların da iştirakının təmin edilməsində əhəmiyyətli rol oynayır [1]. Lakin hər bir vətəndaş elmi layihəsinin formalaşması zamanı qarşıya müəyyən problemlər çıxır. Bunlardan biri də təhlükəsizlik problemidir. Xüsusilə də vətəndaş elmi layihəsi iştirakçılarının fərdi məlumatlarının təhlükəsizliyinin mühafizəsi məsələsi aktual yer alır.

Məqalədə vətəndaş elmi layihələrində fərdi məlumatların təhlükəsizliyi problemləri tədqiq olunmuş və təhlükəsizliyin təmin olunmasının konseptual məsələləri təqdim olunmuşdur.

\section{VӘTӘNDAS ELMİ LAYIHOLӘRINDD İSTIRAKIN SPESIFIK XÜSUSIYYYTLӘRİ VӘ TӘHLÜKӘSIZLIK PROBLEMLORI}

Vətəndaş elmi layihələrinin elmi əhəmiyyətinə baxmayaraq, qeyd etmək vacibdir ki, o, etik vətəndaş elminin inkişafı baxımından bu layihələrdə iştirak edən ayrı-ayrı şəxslər üçün yaranan təhdidlərin bir daha nəzərdən keçirilməsini tələb edir. Onənəvi elmdə alimlərin, mütəxəssislərin fərdi məlumatlarının təhlükəsizliyinin mühafizəsini nəzərdə tutan qanunlar var. Lakin vətəndaş elmində bu, belə deyil. Vətəndaş elmi layihələrində inklüziv iştirakın təmin olunması nəticəsində burada müxtəlif kateqoriyalı insanlar iştirak etmək imkanı əldə edir. Burada inklüzivliyi bir neçə kateqoriyaya bölmək olar:

- Yaş həddi;

- Təhsil səviyyəsi;

- Fiziki vəziyyət;

- Sosiallaşma və $\mathrm{s}$.

Vətəndaş elmində təhlükəsizlik məsələlərini üç qrupa bölmək olar:

- Texniki vasitələrin təhlükəsizliyi;

- Proqram vasitələrinin təhlükəsizliyi;

- İnformasiya təhlükəsizliyi.

Vətəndaş elmi layihələrində iştirak edən könüllülərin fərdi məlumatlarının qorunması, informasiya təhlükəsizliyinin tərkib hissəsi olaraq, aktual məsələ kimi xüsusi əhəmiyyətə malikdir.

Vətəndaş alimlər adətən tədqiqatçı heyət tərəfindən aparılan fəaliyyətə töhfə verir. Bu zaman onlara çox vaxt tədqiqat qrupu üzvlərinin rolları ilə oxşar rollar verilsə də, vətəndaș elmi ilə ənənəvi elm arasındak1 struktur fərqlər normativlərin uyğunsuzluğuna gətirib çıxarır. Bu fərqlər ayrı-ayrı vətəndaş elmi layihələrinin tamlığını, təhlükəsizliyini və ya hədəflərini poza bilər.

Fərdi məlumatlar - birbaşa və ya dolayı yolla müəyyən olunan fiziki şəxsə (fərdi məlumatların subyektinə) aid olan ixtiyari informasiyadır. Fərdi məlumatlar onunla fərqlənir ki, onlar insanın şəxsiyyətini dəyərli iqtisadi xüsusiyyətlərlə birləşdirir [2]. Vətəndaşlar fərdi məlumatlarını öz çoxplanlı onlayn fəaliyyətlərinin izi olaraq qoyur. Bu informasiya onların 


\section{“Informasiya tohlükosizliyinin aktual multidissiplinar elmi-praktiki problemlori” V respublika konfransı, 29 noyabr 2019-cu il}

onlayn fəal şəkildə tranzaksiyalar üçün istifadə etdikləri informasiyadan əhəmiyyətli dərəcədə çoxdur. Telefonlardan tutmuş saatlara, məişət texnikasına, avtomobillərə və şəhərlərə qədər hər şeyin "ağıllı" olması səbəbindən vətəndaşların hərəkətləri və fəaliyyəti hətta onlayn olmadiqda belə qeydə alınır [3]. Şəbəkə mühitində vətəndaşlar öz resurslarını şəbəkəyə ötürmüş olur. Belə ki, hər bir vətəndaş öz fərdi kompüterindən, telefonundan şəbəkəyə daxil olduqda bu qurğudakı verilənlər şəbəkədə açıq olur. $\mathrm{Bu}$ da vətəndaş elminin reallaşması prosesində müxtəlif kateqoriyalı vətəndaşların konfidensiallığı üçün təhlükə və təhdidlər yaradir.

Fərdi məlumatları aşağıdakı kimi kateqoriyalara bölmək olar:

1) Şəxsi məlumatlara vətəndaşın kimliyini müəyyən etməyə imkan verən informasiya aiddir. Bu məlumatlar iki cür ola bilər: sosial və biometrik məlumatlar. Sosial məlumatlara şəxsin telefon nömrəsi, e-mail ünvanı, işlədiyi şirkətin ad,, tutduğu vəzifə və s. aiddir. Biometrik məlumatlara barmaq izləri, nitq xüsusiyyətləri, gözün qüzehli qişası, üz görünüşü və s. aid edilir;

2) Sensitiv (hassas) molumatlar votəndaşın irqi, dini və ya etnik mənşəyini, eləcə də sağlamlığı ilə bağlı informasiyanı aşkar etməyə imkan verən şəxsiyyəti təsdiq edən sənədlərdir;

3) Uşaqlar haqqında molumatlar dedikdə, yetkinlik yaşına çatmamış (adətən 13 yaşdan kiçik) şəxslərin fərdi məlumatları nəzərdə tutulur;

4) Coğrafi məkan haqqında molumatlara verilənlərin toplanıldığı, şəkil və videoların çəkildiyi coğrafi məkanların qeydə alınması aiddir.

\section{OLAQӘDAR İŞLӘR HAQQINDA}

Gündəlik həyatda vətəndaşlar rəqəmsal aləmdə proqram təminatı sistemləri ilə qarşılıqlı təsirdə olur. Bu sistemlər istifadəçilərlə bərabər və ya onların əvəzinə qərar qəbul etməkdə avtonomdur [4]. Çox vaxt bu avtonomluq sistemin sərhədlərini aşır və istifadəçi səlahiyyətlərinə təsir edir. Nəticədə etik problemlər, təhlükəsizlik problemləri də daxil olmaqla (məsələn, fərdi məlumatların icazəsiz alınması) ciddi narahatlığa səbəb olan məsələlər meydana çıxır. Bu problemlər hər bir insanın mənəvi haqlarına təsir göstərir və sosial, iqtisadi, siyasi sahələri əhatə edir [5-7].

Avropa Vətəndaş Elmi Assosiasiyasının (European Citizen Science Association - ECSA) təşəbbüsü ilə bəyan edilmiş "Vətəndaş elminin 10 prinsipi" içərisində fərdi məlumatların təhlükəsizliyinin qorunması ilə bağlı "Vətəndaş elmi layihələrinin liderləri müəllif hüququ, intellektual mülkiyyət, informasiya mübadiləsi haqqinda razılıq (müqavilə), konfidensiallıq, məsuliyyət, ətraf mühitə təsir ilə əlaqədar hüquqi və etik aspektləri nəzərə alır" prinsipi vardır [8].

Fəlsəfi aspektlərlə yanaşı bu problemlərə həm tənzimləyici, həm də texniki baxımdan iki cür yanaşma ola bilər. Avropada Verilənlərin Mühafizəsi üzrə Ümumi Reqlament qanunvericiliyi yaradılmışdır (General Data Protection
Regulation - GDPR). Bu qanunvericilik 2016-c1 il aprelin 27də qəbul edilmiş, 2018-ci il mayın 25-də isə qüvvəyə minmişdir. GDPR-in əsas prinsipləri içərisindəki fərdi məlumatların emalı ilə bağlı prinsiplərə əsasən, fərdi məlumatlar onların subyektinə qarşı qanuni, ədalətli və şəffaf bir şəkildə emal olunmalıdır ("qanunilik, ədalət və şəffaflıq") [9].

Fiziki şəxsin sağlamlığı ilə bağlı fərdi məlumatlarının toplanılmasına iki cür yanaşma mümkündür. Belə ki, bir tərəfdən sağlamlıq problemi olan vətəndaşlar bir-birlərinin diaqnozlarından xəbərdar olmaqla digər oxşar xəstələrdən məsləhət ala bilir, bu isə onlara həm sağlamlıq vəziyyətini yaxşılaşdırmağa imkan verir, həm də mənəvi dəstək olur. Digər tərəfdən, bəzi vətəndaşlar öz fiziki məhdudiyyətlərinin başqalarına məlum olmasını istəmirlər. Bu da onlarda olduqca mənfi reaksiyaya səbəb olar və hətta stress yaradaraq sağlamlıqlarında ciddi problemlərə yol aça bilər. Bu baxımdan vətəndaşların sağlamlığı ilə bağlı məlumatlar həssas (sensitiv) məlumat hesab edilir və bu cür məlumatların gizliliyinin qorunması xüsusi diqqət tələb edir.

Sağlamlıqla əlaqəli həssas məlumatların təhlükəsizliyinin qorunmasını PatientsLikeMe layihəsində öz əksini tapmışdır. Belə ki, burada xəstəliyin tarixi, qoyulmuş diaqnozlar, allergiyalar, cari müalicə və s. kimi tibbi məlumatların yalnız pasiyentlər və tibbi xidmət üçün açıq olması göstərilir [10].

ABŞ-da vətəndaşların, o cümlədən vətəndaş elmi ilə məşğul olanların fərdi məlumatlarının məxfiliyinin qorunması ilə əlaqəli federal qanunlar var [11]. Bu qanunlardan vətəndaş elmi layihələrində ən geniş tətbiq olunan Uşaqların Onlayn Gizliliyinin Qorunması Qanunudur (The Children's Online Privacy Protection Act-COPPA). Bu qanun 13 yaşından kiçik uşaqların şəxsi mlumatlarının toplanılması ilə əlaqədardır. COPPA bir çox, xüsusilə də təhsil komponenti olan layihələri əhatə edir. Tibbi Sı̆gorta Daşınması və Hesabatlılıq Qanunu (Health Insurance Portability and Accountability Act HIPAA) tibbi qeydlərin məxfiliyini qoruyan qanundur. Məxfilik Aktı (Privacy Act) federal qurumların şəxsiyyəti müəyyənləşdirən məlumatları toplaması, istifadə etməsi və paylanmasını məhdudlaşdırır. Bu, federal qurumların özləri tərəfindən maliyyələşdirilən layihələrdə öz tətbiqini tapır. Məlumat Azadlığ 1 Qanunu (The Freedom of Information Act FOIA) vətəndaşların federal hökumət tərəfindən saxlanılan qeydlərə giriş hüququnu təmin edən qanundur. Şəxsiyyəti müəyyənləşdirən məlumatları (personally identifiable information - PII) ictimai qeydlərdən mühafizə edən bu qanun da həmçinin federal qurumların maliyyələşdirdiyi layihələrdə tətbiq edilir.

Elm və Texnologiya Siyasəti İdarəsi (Office of Science and Technology Policy - OSTP) tərəfindən təsdiqlənmiş memorandumlar (www.whitehouse.gov/ostp) bu sahədə ABŞ-1n əlavə mənbələridir. Məsələn, "Federal Maliyyələşdirilən Tədqiqatın Nəticələrinə İctimai Girişin Gücləndirilməsi” adlı bir memorandum agentliklərə şəxsi konfidensiallığın qorunması ilə yanaşı, nəşr olunmuş verilənlərə də giriş imkanını genişləndirməyi təklif edir. 


\section{“Informasiya tohlükosizliyinin aktual multidissiplinar elmi-praktiki problemlori” V respublika konfransı, 29 noyabr 2019-cu il}

Birləşmiş Ştatlar xaricində standartlara İqtisadi Oməkdaşlıq və İnkişaf Təşkilatı (Organization for Economic Cooperation and Development - OECD) tərəfindən təsdiq edilmiş prinsiplər daxildir [12]. Avropa Birliyinin Gizlilik və Elektron Rabitə üzrə Direktivinə görə (E.U.'s Directive on Privacy and Electronic Communications), veb-saytlar, cookie-fayllar daxil olmaqla, verilənlərin toplanılması təcrübələrini açıq şəkildə göstərməlidirlər. Bu direktiv Avropa Birliyində biznes həyata keçirən layihələrə aiddir [13].

İnsan Hüquqları üzrə Avropa Konvensiyasının (European Convention on Human Rights) 8-ci bəndində göstərilmişdir ki, fərdi məlumatlar vətəndaşların hüquqlarının ayrılmaz bir hissəsidir, vətəndaşların şəxsi həyatına və yazışma sirrinə hörmət edilməlidir.

Vətəndaş elmi layihələrinin koordinatorları könüllülərin fərdi məlumatlarını qorumaq məqsədilə texnoloji mühafizə və informasiya siyasətləri kimi bir sira mexanizmləri tətbiq edirlər. Bunlardan məkanın vizual görüntüsünün bulanıqlaşdırılması və ya gizlədilməsi metodu geniş istifadə olunur [14]. Bəzi sistemlərdə vizual görüntüsü bulanıq olan verilənlər olur, yəni dəqiq məkan qeyri-müəyyən edilir. Bunu vətəndaş elmi layihələrinin koordinatorları edir ki, məkanı təkcə özləri görə bilsin. Məkanın vizual görüntüsünün bulanıqlaşdırılması metodu daha çox landşaftı gizlətmək üçün tətbiq edilsə də, insanlar bu metoddan öz yaşayış yerlərinin gizlədilməsi məqsədilə xeyli faydalana bilər.

Toplanılan və paylaşılan şəxsi informasiyanın həcminin minimallaşdırılması konfidensiallığın qorunması üçün istifadə edilən daha bir metoddur. Verilənləri kimin təqdim etdiyinin məlum olması elmi cəhətdən əhəmiyyət kəsb etdiyi üçün, bir çox layihələr könüllünün təqdim etdiyi verilənləri onun adı ilə əlaqələndirir. $\mathrm{Bu}$ cür informasiyanın göstərilməsi barədə seçimdən asılı olaraq vətəndaş elmi layihələrinin koordinatorları könüllülərə hər iki seçimi - həm anonim identifikasiya, həm də öz istifadəçi adlarını yaratmağı təqdim edirlər.

\section{VӘTӘNDAŞ ELMİ LAYİHӘLӘRİNDӘ FӘRDİ MOLUMATLARIN TOHLÜKӘSIZLIYININ TOMIN EDİLMOSININ KONSEPTUAL MOSəLӘLӘRİ}

Virtual aləmdə və vətəndaş elmi layihələrində vətəndaşların şəxsi həyatı haqqında verilənlərin mühafizəsi böyük əhəmiyyətə malikdir. Fərdi məlumatların toplanılması, emalı və saxlanılması məsələlərinin effektiv həlli vətəndaş elmi layihələrinin iştirakçılarının təhlükəsizliyi üçün ən mühüm məsələlərdən biridir [11].

Ölkəmizdə vətəndaşların fərdi məlumatlarının təhlükəsizliyinin qorunması ilə bağlı həyata keçirilən tədbirlər sırasında normativ-hüquqi sənədlər xüsusi yer tutur. "Fərdi məlumatlar haqqinda" AR Qanununun 8-ci maddəsində deyilir: "Azərbaycan Respublikasının qanunvericiliyi ilə müəyyən olunmuş qaydada fərdi məlumatların məcburi şəkildə toplanılması və işlənilməsi halları istisna olmaqla, hər hansı şəxs barəsində fərdi məlumatların toplanılmasına və işlənilməsinə yalnız subyekt tərəfindən verilmiş yazılı, o cümlədən gücləndirilmiş elektron imzalı elektron sənəd formasında razılıq və ya özünün yazılı təqdim etdiyi məlumatlar əsasında yol verilir". Fərdi məlumatların toplanılması, emalı və ötürülməsi yalnız "Fərdi məlumatlar haqqında" Qanuna uyğun olaraq həyata keçirilə bilər.

AR Konstitusiyasının 50-ci maddəsinə görə, hər kəsin istədiyi informasiyanı qanuni yolla axtarmaq, əldə etmək, ötürmək, hazırlamaq və yaymaq azadlığı vardır. Bununla yanaşı, informasiya azadlığının həyata keçirilməsi digər insanların hüquqlarının, azadlıqlarının və qanuni maraqlarının pozulmasina səbəb olmamalidir.

Avropa Vətəndaş Elmi Assosiasiyasının "Vətəndaş elminin on prinsipi" içərisində fərdi məlumatlarla bağlı qeyd etdiyimiz prinsip, eləcə də Verilənlərin Mühafizəsi üzrə Ümumi Reqlament qanunvericiliyi kimi normativ-hüquqi sənədlər ölkəmizdə vətəndaş elmi ilə məşğul olan şəxslərin fərdi məlumatlarının təhlükəsizliyini təmin etmək üçün nəzərə alınmalıdır.

Beləliklə, bu sahədə beynəlxalq təcrübənin nəzərə alınması, həmçinin ölkədə müvafiq normativ-hüquqi sənədlərin hazırlanması və onlara riayət edilməsi vətəndaşların onlayn mühitdə təhlükəsizliyinin təmin edilməsni təmin edəcəkdir.

Vətəndaş elmi layihələri çərçivəsində vətəndaşların fərdi məlumatlarının mühafizəsi məqsədilə görülən tədbirlər proqnozlaşdırıcı, qabaqlayıcı və aradan qaldırıcı olmaqla qruplara bölünərək layihələndirmə prosesində nəzərə alınmalıdır:

1. Proqnozlaşdırıcı tadbirlar mövcud sistemlərdəki potensial təhlükə və təhdidlərin aşkarlanmasını nəzərdə tutur. Bu məsələnin həlli üçün analitik metodlardan istifade olunmalidir.

2. Qabaqlayıcı tədbirlar potensial təhlükənin baş verməsinin qarşısını almaq məqsədilə görülən işlərdir. Qabaqlayıc1 tədbirlərin görülməsi üçün ilk növbədə proqnozlaşdırıcı tədbirlər həyata keçirilməlidir.

3. Aradan qaldırıcı tədbirlor artıq baş vermiş olan təhlükəsizlik problemlərinin həll edilməsində tətbiq olunur. Bu zaman əvvəllər mövcud olmuş və ya baş vermiş təhdidlərin araşdırılması və yox edilməsində istifadə olunan təhlükəsizlik tədbirləri həyata keçirilir.

Vətəndaş elmi layihələrinin veb-saytları, eləcə də istifadə edilən proqram təminatı işlənib hazırlanarkən proqramçılar bu məsələlərə diqqət yetirməlidirlər. Veb-saytın ana səhifəsinin müvafiq bölməsində təhlükəsizlik siyasəti barədə lazımi informasiya qeyd edilməlidir. Bu, layihədə iştirak etmək üçün qeydiyyatdan keçmək istəyən vətəndaşlara qeydiyyatı təhlükəsizlik şərtlərini əvvəlcədən bilərək tamamlamağa imkan verir.

Vətəndaş elmi layihələri çərçivəsində vətəndaşların fərdi məlumatlarının mühafizəsi məqsədilə onlayn mühitdə onların biometrik göstəricilərindən istifadə etmək ən əlverişli və eyni zamanda etibarlı üsullardan biridir. Layihə üçün qeydiyyatdan keçmiş hər bir iştirakçı öz şəxsi səhifəsinə giriş üçün yalnız öz biometrik göstəricilərindən istifadə etməlidir. $\mathrm{Bu}$ isə kənar 


\section{“Informasiya tohlükosizliyinin aktual multidissiplinar elmi-praktiki problemlori” V respublika konfransı, 29 noyabr 2019-cu il}

şəxslərin girişini məhdudlaşdıraraq, iştirakçıların fərdi məlumatlarının gizliliyini qorumaq üçün həyata keçirilir.

Fərdi məlumatların təhlükəsizliyinin təmin edilməsi üçün görülən işlər yuxarıda qeyd olunmuş üç istiqamətdə qurulmalıdır. On yaxşı hal üçüncü mərhələyə ehtiyac olmadığı haldır: belə ki, bütün potensial təhlükə və təhdidlər nəzərə alınarsa, onların qarşısını qabaqcadan almaq mümkün olar. Lakin müasir dövrdə İKT-nin sürətli inkişafi, bu sahədə əldə olunan nailiyyətlər bir tərəfdən həll yolları, digər tərəfdən isə yeni təhlükə və təhdidlər ortaya çıxarır. Buna görə də yuxarıda qeyd etdiyimiz hər üç mərhələ eyni dərəcədə vacib hesab edilməli, bu istiqamətdə fəal işlər aparılmalıdır.

Müxtəlif vətəndaş elmi layihələrinin rəhbərləri bu tədbirləri uğurla tətbiq edərək, öz layihələrində iştirakı onlayn mühitdə vətəndaşlar üçün daha təhlükəsiz və etibarlı edə bilər.

\section{NəTİCə}

Aparılmış araşdırmalar göstərir ki, müasir dövrdə İKT-nin sürətli inkişafı, o cümlədən IoT, şəbəkə və bulud texnologiyalarından istifadə elmin, xüsusən də e-elmin yeni istiqaməti olan vətəndaş elminin geniş tətbiqinə yol açmışdır. Bunun nəticəsi olaraq vətəndaş elmi layihələrinin və onlarda iştirak edən könüllülərin sayı artmışdır. Layihə iştirakçılarının sayı artdıqca onların fərdi məlumatlarının qorunması problemi mürəkkəbləşir. Bu sahədə təhlükəsizlik məsələlərinin nəzərə alınması, lazımi tədbirlərin görülməsi vətəndaşların öz fərdi məlumatları ilə bağlı narahatlıqlarını aradan qaldırmaqla, gələcəkdə vətəndaş elmi layihələrinin iştirakçılarının sayını artıracaq, bununla da vətəndaş elmini daha da inkişaf etdiracəkdir.

\section{İSTINADLAR}

[1] T.X. Fətəliyev, "Vətəndaş elmi e-elmin inkişafının yeni istiqaməti kimi,” İnformasiya cəmiyyəti problemləri, №1, s. 57-64, 2014.

[2] B. Roessler, "Should Personal Data Be a Tradable Good? On the moral limits of markets in privacy" in Beate Roessler and Dorota Mokrosinska (eds), Social Dimensions of Privacy: Interdisciplinary Perspective (Cambridge: Cambridge University Press 2015)

[3] M. Autili, D. Di Ruscio, P. Inverardi, P. Pelliccione, M. Tivoli, "A software exoskeleton to protect and support citizen's ethics and privacy in the Digital World”, IEEE Access, 19 May 2019, pp.62011-62021.

[4] P. Inverardi, "The european perspective on responsible computing", Commun. ACM, vol. 62, no. 4, pp. 64, Mar. 2019.
[5] European Group on Ethics in Science and New Technologies, 2018, https://ec.europa.eu/research/ege/pdf/egeaistatement2018.pdf

[6] J. P. Burgess, L. Floridi, A. Pols, J. van den Hoven, Towards A Digital Ethics-EDPS Ethics Advisory Group, 2018 , https://edps.europa.eu/sites/edp/files/publication/18-0125_eag_report_en.pdf

[7] Leading by Example The EDPS Strategy 2015-2019, 2015, [online] Available: https://edps.europa.eu/sites/edp/files/publication/15-0730_strategy_2015_2019_update_en.pdf

[8] 10 Principles of citizen science, https://ecsa.citizen-science.net/engageus/10-principles-citizen-science

[9] GDPR, https://gdpr-info.eu/art-5-gdpr/

[10] J.H. Frost, M.P. Massagli, Social Uses of Personal Health Information Within PatientsLikeMe, an Online Patient Community: What Can Happen When Patients Have Access to One Another's Data. Journal of Medical Internet Research, 2018, doi: 10.2196/jmir.1053.

[11] Т.Х. Фаталиев, Н.Н. Вердиева, Вопросы обеспечения информационной безопасности в проектах гражданской науки, VII Международная научно-практическая конференция “Информационные технологии: проблемы и решения". Уфа, 2019, cc. 50-55.

[12] OECD Guidelines on the Protection of Privacy and Transborder, www.oecd.org/internet/ieconomy/oecdguidelinesontheprotectionofpriva cyandtransborderflowsofpersonaldata.htm

[13] A. Bowser and o., "Sharing data while protecting privacy in citizen science", İnteractions, Vol. 21, Issue 1, 2014, pp. 70-73.

[14] B. Sullivan, et al., "The eBird enterprise: An integrated approach to development and application of citizen science", Biological Conservation 169, 2014, pp.31-40.

\section{ISSUES OF ENSURING SECURITY OF PERSONAL DATA IN CITIZEN SCIENCE PROJECTS} Nargiz Verdiyeva

Institute of Information Technology of ANAS, Baku, Azerbaijan

depart3@iit.science.az

Abstract- The article is dedicated to the issues of ensuring security of personal information of citizens participating voluntarily in citizen science projects. Citizens' personal data are categorized and classified. Regulatory and legal documents providing security of personal data are reviewed. Ways of protecting personal information of citizens in existing citizen science projects are analyzed. Based on the research carried out, the work done in this direction in our country is analyzed and recommendations are made.

Keywords-e-science; citizen science; security; personal data; sensitive information. 